Journal of The Faculty of Science and Technology (JFST)

http://journal.oiu.edu.sd/index.php/JFST

https://doi.org/10.52981/jfst.vi7.961

ISSN: 1858 - 6007

مجلة العلوم و التقانة - جامعة أم درمان الإسلامية - وزارة التعليم العالي و البحث العلمي ـ السودان

Research article

JFST Issue No. 7 (2020) 93 - 109

\title{
The Relationship between Metrological Parameters and Total Airborne Pollen Concentration in Atmosphere of Khartoum City During 2018
}

\author{
Ejlal Sanad Mohammed Motwaly ${ }^{1}$, A.G. Elfadil ${ }^{1}$, Ahmed Mudawi Musa ${ }^{2}$ \\ ${ }^{1}$ Department of Biology and Biotechnology, College of Science and Technology, Al- \\ Neelain University, Khartoum Sudan. \\ ${ }^{2}$ Department of Environmental Science, College of Science and Technology, Al-Neelain \\ University, Khartoum Sudan. ${ }^{3}$ Institute of Epidemic diseases Khartoum University of \\ Khartoum, Sudan.
}

\begin{abstract}
:
This study is aimed to find out the effect and relationship between metrological parameters and total airborne pollen concentration in atmosphere in Khartoum city (Sudan). For that purpose, one-year data during 2018 of Total Airborne Pollen Concentration (TAPC) and meteorological parameters is utilized. Pollen concentration in the atmosphere was measured using Non-volumetric air sampler (Vertical cylinder spore trap). The descriptive statistic of TAPC and metrological parameters were presented. The result showed TAPC in 2018 reached to their maximum in August (37.5/ $\left.\mathrm{m}^{3}\right)$, and the minimum in June $\left(14 / \mathrm{m}^{3}\right)$. Analysis of the relationship between TAPC and meteorological parameters showed that variations in the pollen concentrations were mainly affected by maximum temperature. In addition, there were substantial differences in these relationships in different seasons. In Autumn, they were affected by the rain falls, maximum temperature and relative humidity; in summer, they were affected by maximum temperature; and in winter, they were affected by maximum temperature and relative humidity. Temperature, rain falls and relative humidity promote plant growth and blooming. As well as the results show wind direction was significant on seasonally TAPC especially in Autumn. The results found significant effects between the meteorological on TAPC, were it is showed $72 \%$ are affecting on TAPC refer to meteorological parameters and $28 \%$ refer to another factors.
\end{abstract}

Keywords: Airborne Pollen, Meteorological Parameters, Khartoum 


\section{Introduction:}

Pollen has a very important role to trigger allergic respiratory diseases. Human health is directly affected due to the presence of their high concentration in the atmosphere (Muhammad \& Ghulam, 2008). Regional pollen concentrations vary with climate, geography, vegetation and distance from the emission source (Scheifinger, et al., 2013). Airborne pollen concentrations are also highly influenced by meteorological variables such as temperature, wind, humidity, precipitation, and strong convection weather (Reico, et al., 2018; Linkosalo, et al., 2010; Agashe, \& Elfadil, 1990). Temperature plays a very important role in increasing the concentrations of airborne pollen (Garc1 'a-Mozo, et al., 2016; Frei, 1998). It is the main factor controlling the start of the grass pollen season and the timing of peak pollen counts (Frenguelli, et al., 1989; Gala'n, et al., 1995). Relative humidity and precipitation hinder emission and pollen dispersion, as it was demonstrated for ragweed in several aerobiological studies (Bartkova-Scevkova, et al., 2003; Puc, 2004). Changing wind speed and direction and other weather elements affect pollen transportation, and these factors are important in global pollen dispersal (Ediger, et al., 1997). In Khartoum city the TAPC were studied in 2018 varied significantly in different seasons, the pollen concentrations were at a maximum in autumn $\left(128.1 / \mathrm{m}^{3}\right)$, followed by winter $\left(87.4 / \mathrm{m}^{3}\right)$ then summer $\left(83.5 / \mathrm{m}^{3}\right)$ (Mohammed, et al., 2020). Main aim of this study to find effect and relationship between meteorological which are affecting pollen in the atmosphere of Khartoum city.

\section{Materials and Methods}

\section{Study area and climate}

Khartoum City is the capital of Sudan; it is located in the middle of the populated areas in Sudan; between the Blue and White Niles; at almost the northeast center of the country between latitudes $15^{\circ}$ and $16^{\circ}$ north; and between longitudes $31^{\circ}$ and $32^{\circ}$ east; occupying an area of about $28165 \mathrm{Km}^{2}$ (Wikipedia.Org.com. 2018).

Climate: Under Köppen's climate classification system, Khartoum features a hot arid climate, with only the summer months seeing noticeable precipitation.

The city averages a little over 155 millimeters (6.1 in) of precipitation per year. Based on annual mean temperatures, the city is one of the hottest major cities in the world. Temperatures routinely exceed $40 \mathrm{C}^{\circ}\left(104^{\circ} \mathrm{F}\right)$ in mid-summer. Its average annual high temperature is $37.1 \mathrm{C}^{\circ}\left(99^{\circ} \mathrm{F}\right)$, with six months of the year seeing an average monthly high temperature of at least $38 \mathrm{C}^{\circ}\left(100^{\circ} \mathrm{F}\right)$. Furthermore, throughout the year, none of its 
monthly average high temperatures falls below $30 \mathrm{C}^{\circ}\left(86^{\circ} \mathrm{F}\right)$. During the months of January and February, while daytime temperatures are generally very warm, nights are relatively cool, with average low temperatures just above $15 \mathrm{C}^{\circ}\left(59^{\circ} \mathrm{F}\right)$ (Peel \& et.al, 2007).

\section{Aeropalynological survey}

One -year data (from 1 January to 31 December in 2018) of daily pollen concentration and meteorological parameters is used in this study. Pollen monitoring was done using Nonvolumetric air sampling (Vertical cylinder spore trap) (Agashe \& Elfadil,1989a). The sampler was located at the Faculty of Science and Technology on the $2^{\text {nd }}$ floor of the main building at Al-Neelain University (20 meters above ground level). Pollens were analyzed under a microscope and were manually counted for total pollen concentration. In the counted for total pollen concentration we used the average monthly and seasonally values.

\section{Meteorological parameters survey}

Six meteorological parameters viz: maximum and minimum temperature, relative humidity, rainfall, wind speed and direction. To determine the correlation between airborne pollen concentration and meteorological parameters in Khartoum based on sampling from 2018. The monthly average and seasonal values of metrological parameters were used. All the meteorological parameters data collected during 2018 obtained from the Ministry of Environment, Forestry and Physical Development, Metrological Authority- Weather Climate Data of Sudan.

\section{Statistical analysis}

Analysis of TAPC data and metrological parameters in 2018, as well as the correlation between seasonal pollen concentration and 6 meteorological parameters. Spearman's correlation coefficient was used. All statistical analyses were performed using the SPSS Statistics 22 for windows.

\section{Results and Discussion}

\section{Descriptive statistic of TAPC / $\mathbf{m}^{3}$ in 2018}

The results of descriptive statistic of monthly TAPC in 2018 showed the mean of TAPC was (24.91) with Standard deviation (6.872), where the results showed maximum concentration was (37.5) in month of August, while the minimum concentration was (14) 
in June presented in figure (1) the TAPC followed with normal curve presented in figure (2).

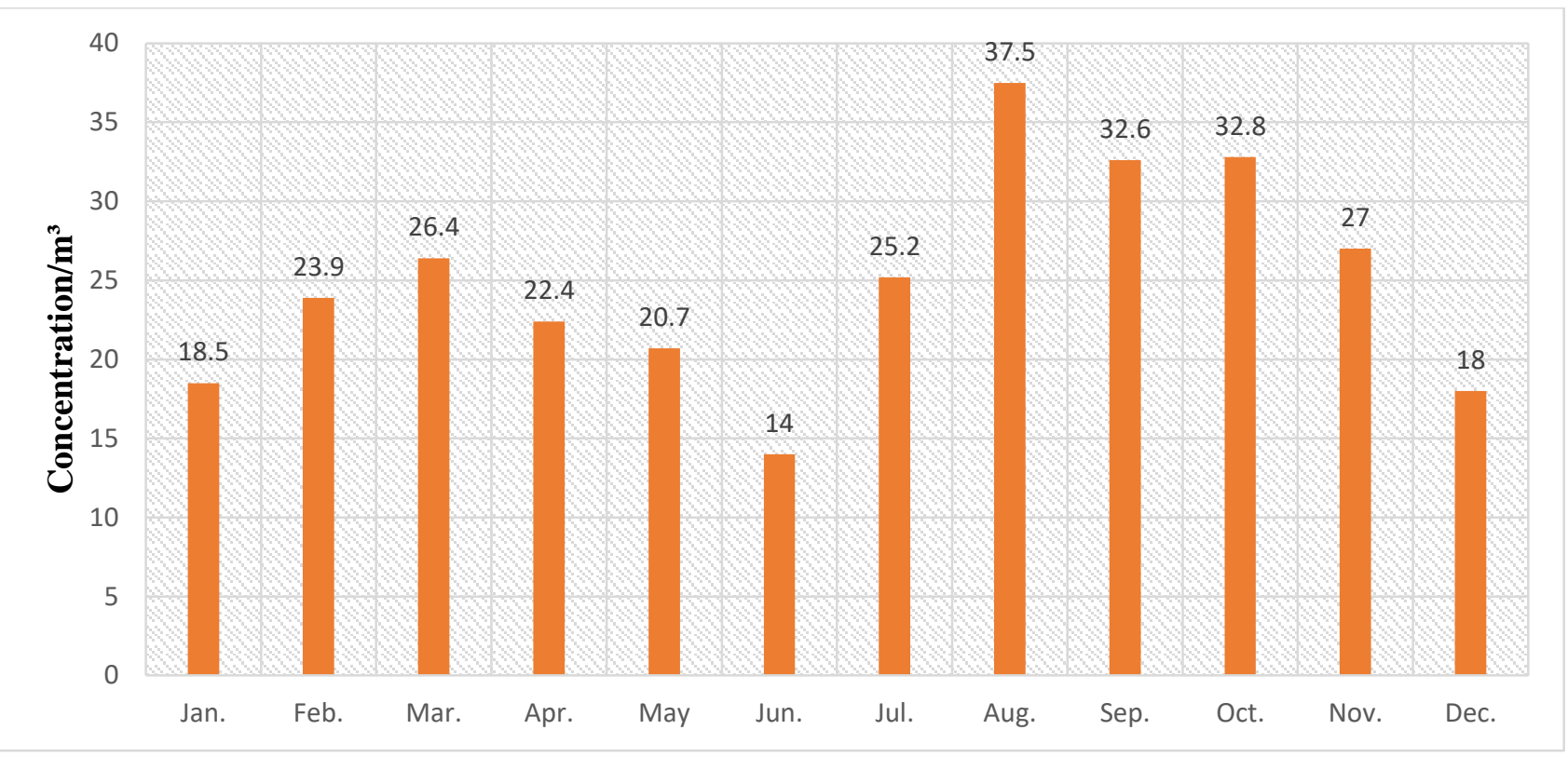

Figure (1): Monthly (TAPC)/ $\mathrm{m}^{3}$ in 2018

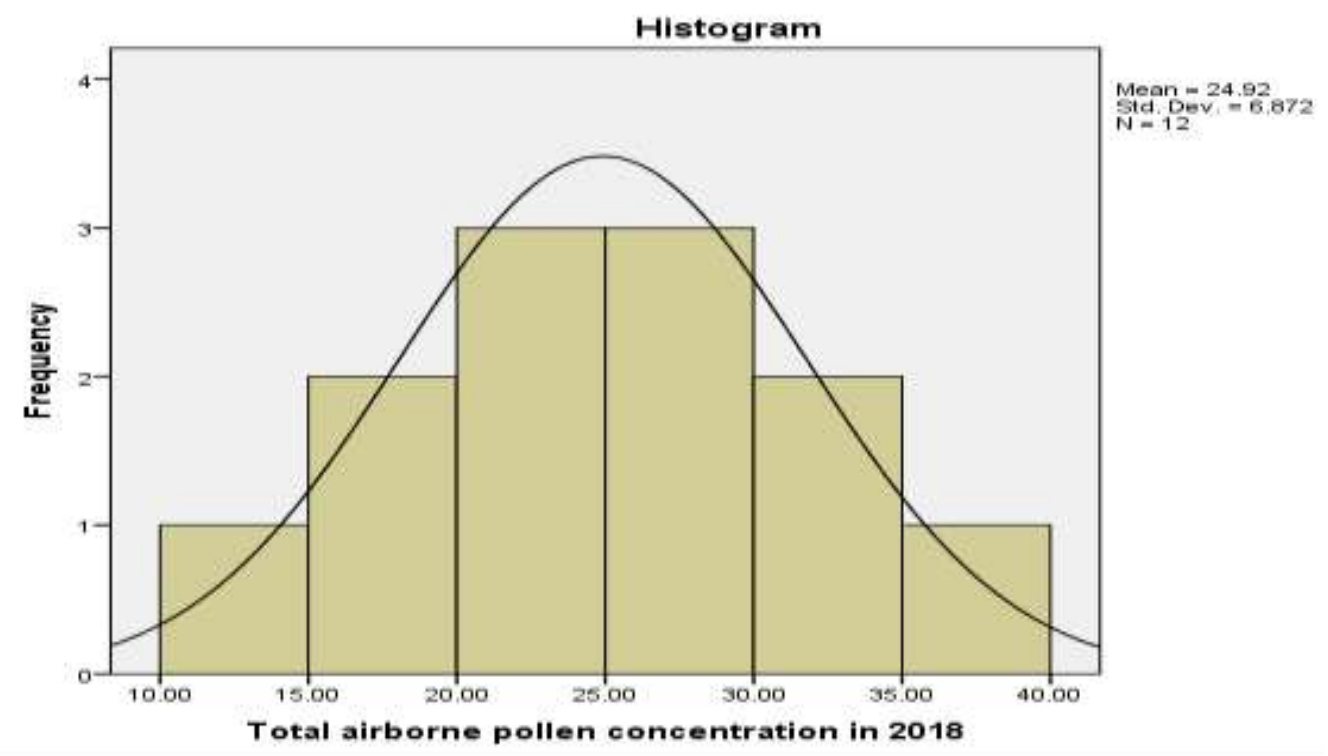

Figure (2): Normal curve of TAPC / $\mathrm{m}^{3}$ in 2018 


\section{Descriptive Statistic of Meteorological Parameters in 2018}

The results of descriptive statistic of meteorological parameters data in 2018 showed the mean of maximum temperatures was $\left(36.56 \mathrm{C}^{\circ}\right)$ with standard deviation $(3.950)$, where the highest degree $\left(40.1 \mathrm{C}^{\circ}\right)$ in month of June and minimum degree $\left(29.4 \mathrm{C}^{\circ}\right)$ in January. Also the mean minimum temperatures were $\left(23.36 \mathrm{C}^{\circ}\right)$ with standard deviation $(3.204)$, and the highest degree $\left(28 \mathrm{C}^{\circ}\right)$ in month of May, and the lowest in January $\left(15.4 \mathrm{C}^{\circ}\right)$. The results showed the mean of relative humidity was (25.16\%) with standard deviation (11.953) and the highest degree was (45\%) in month of September and the lowest is (8\%) in April, the results showed the mean of total rain falls was $(8.96 \mathrm{~mm})$ with standard deviation (14.701), where the highest in July $(34.3 \mathrm{~mm})$ followed by September $(33.6 \mathrm{~mm})$, August $(31.7 \mathrm{~mm})$ and trace in October, in the other months they were no any rains record. From wind speed founded the mean reached (8.66 Knots) with standard deviation (1.071), where the highest speed is (11 / Knots) in January and the lowest is (7 / Knots) in May and October all this in table (1) fig. (3). The present results are in consistent with previous observation in different countries (Puc \& Wolski, 2002; Vega-Maray, et al., 2003; Boral, et al., 2004).

Table (1): Descriptive statistic of meteorological parameters in 2018

\begin{tabular}{|l|l|l|l|l|}
\hline Variable & Mean & SD & Min & Max \\
\hline Maximum temperature & 36.56 & 3.950 & 29.40 & 41.80 \\
\hline Minimum temperature & 23.36 & 3.204 & 15.40 & 28.00 \\
\hline Relative humidity & 25.16 & 11.953 & 8 & 45.00 \\
\hline Total rain fall (MM) & 8.96 & 14.701 & .00 & 34.30 \\
\hline Wind speed (Knots) & 8.66 & 1.0730 & 7.00 & 11.00 \\
\hline
\end{tabular}


Meteorological parameters in 2018

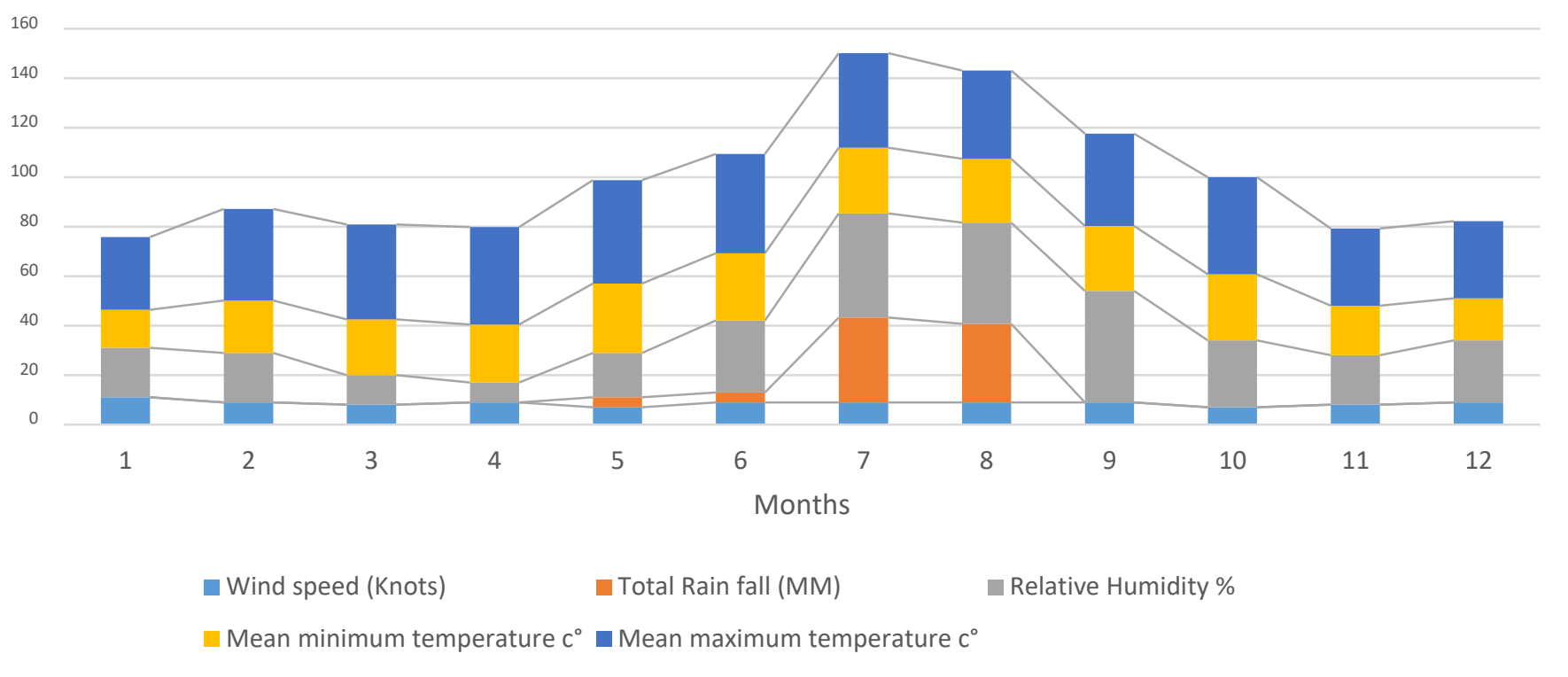

Figure (3): The meteorological parameters data collected during (2018)

\section{Wind Direction in 2018}

The results of descriptive statistic of wind direction in 2018 showed (58\%) of wind comes from North of Sudan (7 months), while it is (26\%) comes from South west (3 months) and that reflects most of wind comes from North direction, presented in table (2) fig. (4).

Table (2): Descriptive statistic of wind direction in 2018

\begin{tabular}{|l|l|l|}
\hline Direction & Count & \% \\
\hline North & 7 & $58 \%$ \\
\hline North East & 1 & $8 \%$ \\
\hline South & 1 & $8 \%$ \\
\hline South West & 3 & $26 \%$ \\
\hline Total & $\mathbf{1 2}$ & $\mathbf{1 0 0 \%}$ \\
\hline
\end{tabular}




\section{TAPC / $\mathrm{m}^{3}$ in 2018 by Wind direction}

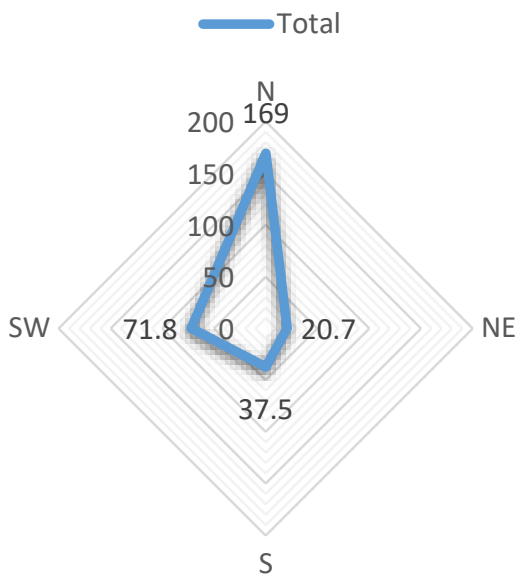

\section{Figure (4): The TAPC / $\mathrm{m}^{3}$ in 2018 by Wind direction in (2018)}

From figure (1), (3) and (4) we found the highest TAPC in August (37.5/ $\left.\mathrm{m}^{3}\right)$, were the mean of maximum temperatures is $\left(35.6 \mathrm{C}^{\circ}\right)$, while the minimum temperatures are $(25.8$ $\left.\mathrm{C}^{\circ}\right)$, with high relative humidity $(41 \%)$ and total rain falls $(31.7 \mathrm{~mm})$, medium wind speed (9 / Knots) and the wind comes from South of Sudan presented in fig. (5). This results have shown that humidity and rain falls appear to be the predominant factors in determining the grass pollen potential for the season Subiza et al. (1992), it is evidenced that temperature is the factors exerts the greatest influence on the release of pollen grains in atmosphere (Puc, 2003; Vega-Maray, et al., 2003).

\section{The relationship between metrological parameters and TAPC in 2018 \\ Mean maximum temperature $c^{\circ} \longrightarrow$ Mean minimum temperature $c^{\circ}$ \\ Relative Humidity \% \\ Total Rain fall (MM) \\ wind speed (Knots)

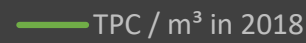

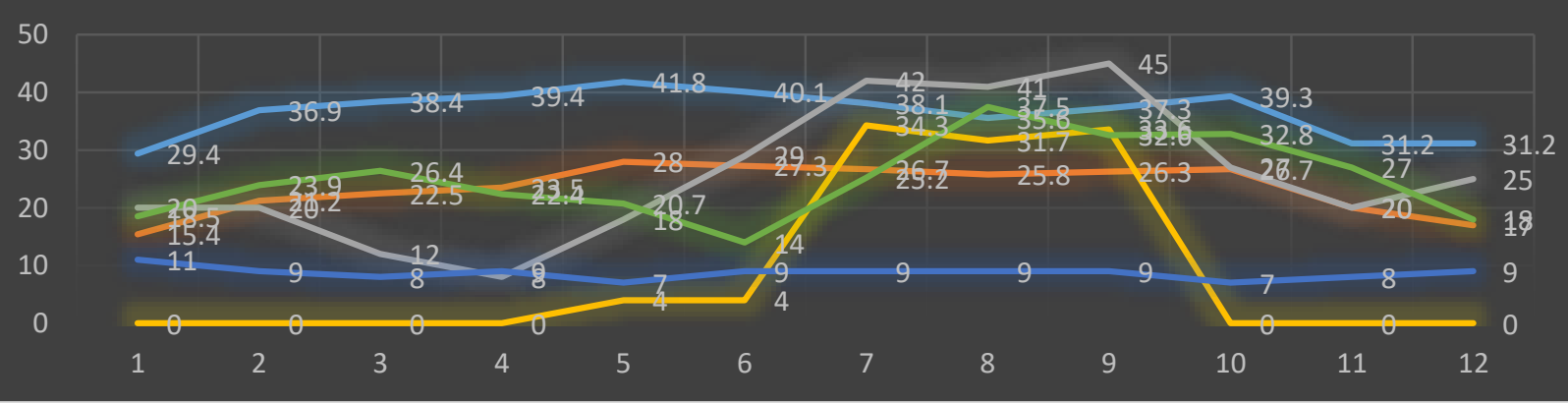

Figure (5): The relationship between metrological parameters and TAPC in 2018 


\section{Descriptive statistic of Seasons in 2018}

In autumn the highest TAPC is $\left(128.1 / \mathrm{m}^{3}\right)$, were the mean of maximum temperatures is $\left(37.57 \mathrm{C}^{\circ}\right)$, while the minimum temperatures are $\left(26.37 \mathrm{C}^{\circ}\right)$, with the highest relative humidity $(41 \%)$ and total rain falls $(24.9 \mathrm{~mm})$, medium wind speed (8.5 / Knots) and most of the wind comes from South West and South of Sudan presented in table (3). In similar study Puc and Wolski 2002 showed a positive and statically significant correlation between air and temperature and the Betula pollen concentration (Feher \& Jaria- Komlodi, 1996).

Table (3):

\begin{tabular}{|l|l|l|l|l|l|l|}
\hline Season & Mean & Mean & Relative \\
& $\begin{array}{l}\text { maximum } \\
\text { temperature } \\
\mathrm{c}^{\circ}\end{array}$ & $\begin{array}{l}\text { minimum } \\
\text { temperature } \\
\mathrm{c}^{\circ}\end{array}$ & $\begin{array}{l}\text { Total } \\
\%\end{array}$ & $\begin{array}{l}\text { Wind } \\
\text { Rain } \\
\text { fall } \\
(\mathrm{MM})\end{array}$ & $\begin{array}{l}\text { Wind } \\
\text { (Knots) }\end{array}$ & $\begin{array}{l}\text { Direction } \\
\end{array}$ \\
\hline Autumn & 37.57 & 26.37 & 38.75 & 24.90 & 8.50 & S,SW,SW,N \\
\hline Winter & 32.17 & 18.40 & 20.50 & 0.00 & 9.25 & N \\
\hline Summer & 39.92 & 25.32 & 16.75 & 2.00 & 8.25 & N,N,NE,SW \\
\hline
\end{tabular}

\section{Analysis of relationship between TAPC and major meteorological parameters in} Khartoum city in 2018

Analysis of the relationship between TAPC and meteorological parameters showed that variations in the pollen concentrations were mainly affected by maximum temperature. In addition, there were substantial differences in these relationships in different seasons presented in table (4):

In autumn, results of pollen concentrations were mainly affected by total rain falls $(\mathrm{r}=0.991, \mathrm{p}<0.01)$ with $\mathrm{P}$-value $=0.009$ and this value smaller than 0.01 , so this result showed a strong and highest significant positive correlation and explain a strong confidence relationship between TAPC and total rain falls. As well as results of pollen concentrations were affected by maximum temperature $(\mathrm{r}=0.952, \mathrm{p}<0.05)$ with $\mathrm{P}$-value $=0.048$ and this value small than 0.05 , so this result showed a strong and significant positive correlation and explain a strong confidence relationship between them. Also the relative humidity had significant positive correlation $(r=0.943, \mathrm{p}<0.05)$ with $\mathrm{P}$-value $=0.057$ and this explain 
a positive relationship between them. The results showed minimum temperature had correlation $(\mathrm{r}=0.543, \mathrm{p}<0.05)$ with $\mathrm{P}$-value $=0.457$ and this value bigger than 0.05 but not significant and that can explain existed of relationship just in study sample and cannot generalize on all community. In the other hand, wind speed not affected by TAPC, correlation $(\mathrm{r}=0.028, \mathrm{p}<0.05)$ with $\mathrm{P}$-value $=0.972$, no found a relationship between them.

In summer, results of pollen concentrations were mainly affected by maximum temperature had significant positive correlation $(r=0.742, \mathrm{p}<0.01)$ with $\mathrm{P}$-value $=0.004$ and this explain a positive relationship between them. In the other hand, wind speed had negative correlation $(\mathrm{r}=0.752, \mathrm{p}<0.05)$ with $\mathrm{P}$-value $=0.248$. The results not affected on minimum temperature, relative humidity and total rain falls. As in Abha city (Saudia Arabia), the study showed June presented the months of highest pollen number, also it found that pollen concentration had negatively correlated with rain fall, relative humidity and wind velocity, but same result in pollen concentration is positively correlated with temperature. (Alwadie, 2008).

In winter, results of pollen concentrations were mainly affected by maximum temperature had significant positive correlation $(\mathrm{r}=0.602, \mathrm{p}<0.05)$ with $\mathrm{P}$-value $=0.028$, also relative humidity had significant positive correlation $(r=0.740, \mathrm{p}<0.05)$ with P-value $=0.026$ and this explain a positive relationship between them. In other parameters we found a relationship but not significant, were with P-value bigger than (0.05) and that explain existed of relationship just in study sample and cannot generalize on all community. In Islamabad five years' data (2003-2007) of pollen concentration and meteorological parameters is utilized. Extremely high pollen concentration in the month of March and relatively less high concentration in July are recorded. Also the study showed that relative humidity, max temperature, min temperature and precipitation of winter months (December, January, February) are the factors which influence pollens of paper mulberry tree and hence total pollen concentration in March-April. (Muhammad and Ghulam, 2008). 
Table (4): Correlation analysis between metrological parameters and TAPC in (2018)

\begin{tabular}{|c|c|c|c|}
\hline \multirow{2}{*}{ Season } & \multirow{2}{*}{$\begin{array}{l}\text { meteorological } \\
\text { parameters }\end{array}$} & \multicolumn{2}{|l|}{ airborne pollen } \\
\hline & & Person correlation & $\mathrm{P}$-value \\
\hline \multirow{5}{*}{ Autumn } & Maximum temperature & 0.952 & $0.048 *$ \\
\hline & Minimum temperature & 0.543 & 0.457 \\
\hline & Relative humidity & 0.943 & $0.057 *$ \\
\hline & Total rain fall (MM) & 0.991 & $0.009 * *$ \\
\hline & Wind speed (Knots) & 0.028 & 0.972 \\
\hline \multirow{5}{*}{ Summer } & Maximum temperature & 0.742 & $0.004 * *$ \\
\hline & Minimum temperature & 0.838 & 0.162 \\
\hline & Relative humidity & 0.809 & 0.191 \\
\hline & Total rain fall (MM) & - & - \\
\hline & Wind speed (Knots) & -0.752 & 0.248 \\
\hline \multirow[t]{5}{*}{ Winter } & Maximum temperature & 0.602 & $0.028 *$ \\
\hline & Minimum temperature & 0.146 & 0.854 \\
\hline & Relative humidity & 0.740 & $0.026 *$ \\
\hline & Total rain fall (MM) & - & - \\
\hline & Wind speed (Knots) & 0.119 & 0.881 \\
\hline
\end{tabular}

**. Correlation is significant at the 0.01 level (2-tailed).

*. Correlation is significant at the 0.05 level (2-tailed) -

Compare means of seasonally TAPC with wind directions in Khartoum city 2018

The results show wind direction was significant on seasonally TAPC, were the F-value = 10.400 and that was a big value and it show strong significant, so it means wind direction effected on TAPC, were we found in Autumn the highest mean of TAPC (32.025) and that 
maybe from rain falls precipitation, while it was (21.8500) in Winter and (20.875) in Summer presented in table (5) fig. (6). The magnitude and quality annual pollen load in the atmosphere varies significantly. Metrological parameters like temperature, rain fall, wind velocity responsible for fluctuation in pollen concentration (Anderson, 1980; Bricchi et al., 1992).

Table (5): Compare means of seasonally TAPC with wind directions in Khartoum city 2018

\begin{tabular}{|l|c|c|c|c|}
\hline \multicolumn{1}{|c|}{ Season } & N & Mean & SD & F-value \\
\cline { 1 - 4 } Autumn & 4 & 27.15 & 4.284 & \multirow{2}{*}{$10.400 * *$} \\
\hline Winter & 4 & 22.55 & 10.339 & \\
\hline Summer & 4 & 25.05 & 5.809 & \\
\hline Total & $\mathbf{1 2}$ & $\mathbf{2 4 . 9 1}$ & $\mathbf{6 . 8 7 2}$ & \\
\hline
\end{tabular}

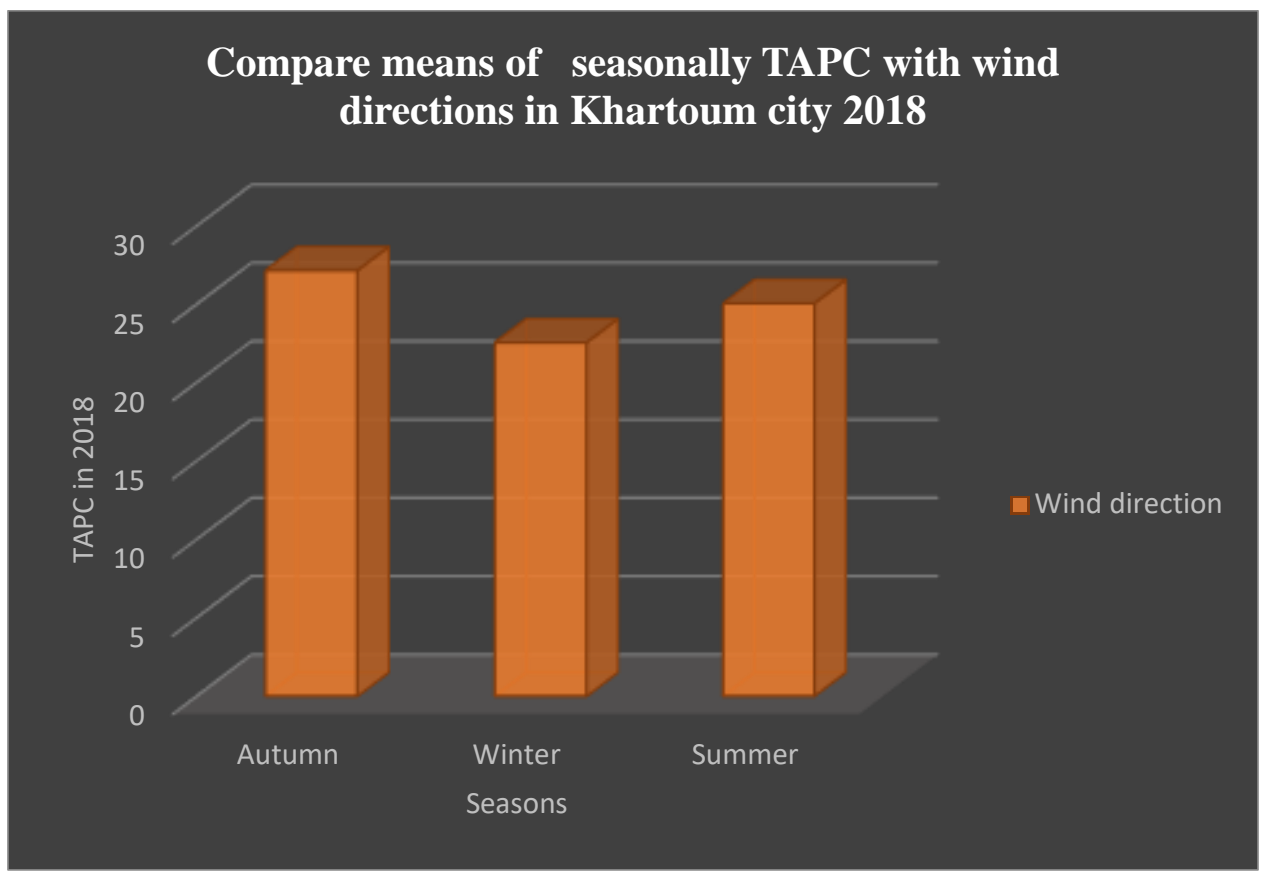

Figure: (6) Compare means of seasonally TAPC with wind directions in Khartoum city 2018 


\section{Compare means of TAPC with Wind directions in Khartoum city 2018}

The results show differences variance on TAPC in different wind direction, which the mean of TAPC from north was (24.14), while it was (37.5) from South, (20.7) from North East and (23.93) from South West. This result showed the south wind share with big part of pollen, presented in table (6), fig. (7). Near results in Szczecin (Poland) statistically significant correlations have been found between the grass pollen count in the air and the maximum wind speed, air temperature, amount of precipitation and relative air humidity. The pollen count of grass is determined by the diversity of local flora and weather conditions, especially by the air temperature and relative humidity (Puc \& Puc, 2004).

Table (6): Compare means of TAPC with Wind directions in Khartoum city 2018

\begin{tabular}{|l|c|c|c|}
\hline \multicolumn{1}{|c|}{ Direction } & N & Mean & SD \\
\hline North & 7 & 24.14 & 5.178 \\
\hline North East & 1 & 20.70 & - \\
\hline South & 1 & 37.50 & - \\
\hline South West & 3 & 23.93 & 9.364 \\
\hline Total & $\mathbf{1 2}$ & $\mathbf{2 4 . 9 1}$ & $\mathbf{6 . 8 7 2}$ \\
\hline
\end{tabular}

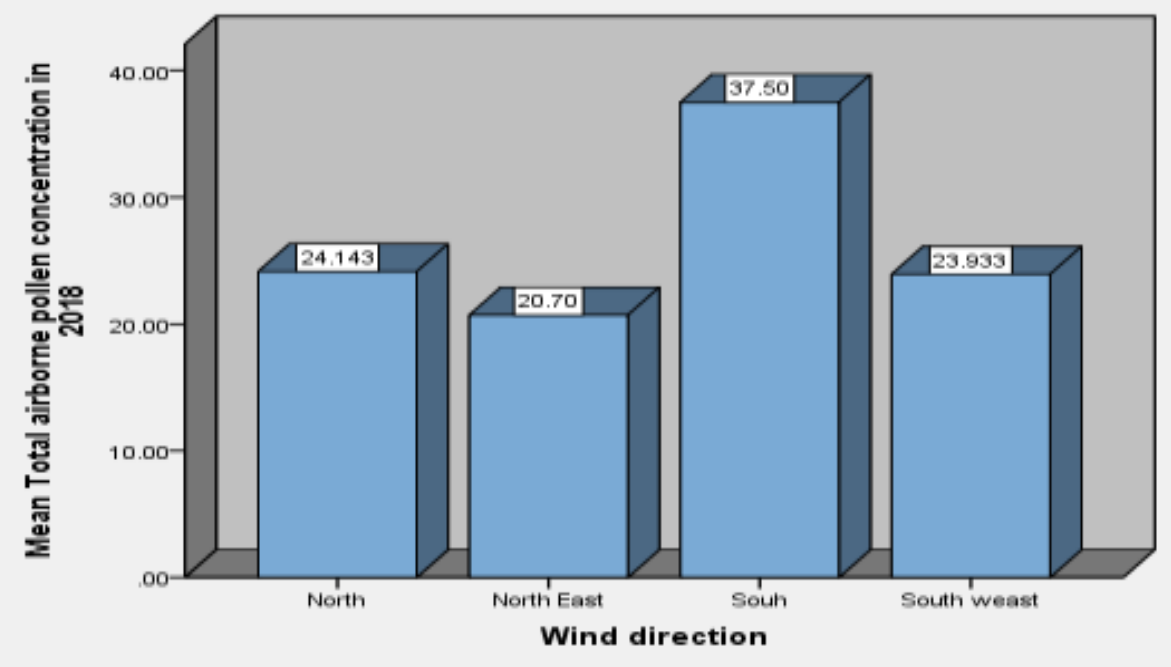

Figure: (7) Compare means of TAPC with wind directions in Khartoum city 2018 
According to numerous authors, temperature in the period preceding pollen shedding has a significant impact on the beginning of the pollen season (Frenguelli, et al. 1991; Frei, 1998; Rodriguez-Rajo, et al. 2004; Emberlin, et al. 2007; Kim, et al. 2011; PiotrowskaWeryszko, 2013; Filbrandt-Czaja \& Adamska 2018; Kubik-Komar, et al. 2018) and this agree with our study.

\section{Multi Regression: between the meteorological and TAPC}

The results found significant effects between the meteorological on total airborne pollen grains concentration, were it is showed from value of $\mathrm{R}^{2}=0.725$ and this value explain 72 $\%$ from change of TAPC refer to meteorological parameters and $28 \%$ refer to another factors, also the results showed value of $F$ value $=11.381$ and this big value so can explain the model is significant and can use it to prediction presented in table (7).

Table (7): Multi Regression: between the meteorological \& TAPC

\begin{tabular}{|l|l|l|l|}
\hline $\mathrm{R}$ & $\mathrm{R}^{\mathbf{2}}$ & F-value & Durbin-Watson \\
\hline 0.731 & 0.725 & 11.381 & 2.384 \\
\hline
\end{tabular}

Near results in central Zhanjiang (China) the pollen assemblages from (June 1, 2015 to June 1,2016) are significantly affected by the flowering times of individual plant taxa, and the total pollen concentrations vary substantially on a seasonal basis. Pollen concentrations are highest in spring, followed by autumn and winter, and lowest in summer. On an annual basis, the airborne pollen assemblages were significantly correlated with temperature and relative humidity. Temperature and relative humidity will promote plant growth and flowering. The variable wind direction in summer and the increased wind speed in winter and spring are conducive to pollen dispersion (Bishan \& et al., 2020).

\section{Conclusion:}

This study is first kind in Khartoum city (Sudan). Analysis of the TAPC load in the atmosphere of Khartoum city (Sudan) varies significantly on seasonal basis, pollen concentrations are highest in autumn. TAPC were significantly and positive correlated with temperature, rain falls, relative humidity and wind direction, while it is negative correlated with wind speed and minimum temperature. Temperature, total rain falls, relative humidity 
and wind direction during the year are affecting on pollen concentration and arising of pollinoisis and allergic respiratory dieses.

In this study we found the highest total pollen grains concentration in 2018 in month of August, and in season of autumn, were in autumn this results explain this value of metrological parameter make a suitable and best condition to promote plant growth and blooming.

The results found significant effects between the meteorological on total airborne pollen grains concentration, were it is showed $72 \%$ from change of TAPC refer to meteorological parameters and $28 \%$ refer to another factors.

From all this results we concluded that effect of metrological parameters on TAPC and that effected by season and that change between season and other.

This work has been financed by the ministry of Higher Education

\section{References}

Agashe, S. N. \& Elfadil, A. G. (1990). Role of meteorological factors in the distribution of airborne pollen and its implication in pollen allergy. The $4^{\text {th }}$ International Conference of Aerobiology at Stockholm, Sweden.

Agashe, S. N. \& Elfadil, A. G. (1989a). Correlation of meteorological parameters to the pollen counts of Amaranth-Chenopod and the symptom of respiratory allergy. Presented at the $23^{\text {rd }}$ Annual Convention of Indian College of Allergy and Applied Immunology, Hyderabad, India.

Alwadie, H. M. (2008). Pollen Concentration in the Atmosphere of Abha City, Saudi Arabia and its Relationship with Meteorological parameters. J Appl Sci. 8 (5):842-847.

Anderson, S.T. (1980). Influence of climatic variation on pollen season severity in wind pollinated tree and herbs. Grana, 19: 47-52.

Bartkova-Scevkova J. (2003). The influence of temperature, relative humidity and rainfall on the occurrence of pollen allergens (Betula, Poaceae, Ambrosia artemisiifolia) in the atmosphere of Bratislava (Slovakia). Int. J Biometeorol. 48: 1-5. https://doi.org/10.1007/s00484-003-0166-2 PMID: 12690548.

Bishan, C., L. Bing, C. Chixin, S. Junxia, Z. Shulin and L. Cailang (2020). Relationship between airborne pollen assemblages and major meteorological parameters in Zhanjiang, South China. PLoS ONE 15(10): e0240160. https://doi. org/10.1371/journal.pone.0240160. 
Bricchi, E., M. Fornaciari, F. Giannoni, D. Greco, D. Fascini and G. Frengvelli (1992). Fluctuations of grass pollen content in the atmosphere of East Perugia and metrological correlation year (1989). Aerobiologia, 8: 401-406.

Boral, D., S. Chatteriee and K. Bhattacharya (2004). The occurrence and allergising potential of airborne pollen in west Bengal. India. Ann. Agrc. Environ. Med., 11:45- 52.

Ediger V., V. S. Ediger and M. Ergin (1997). Transportation of coniferous bisaccate pollen from land to sea and deposition along the shelf off Erdemli (Turkey), NE Mediterranean Sea. B. Geofis. Teor. Appl. 38 (3): 307-321.

Emberlin, J., M. Smith, R. Close and B. Adams-Groom (2007). Changes in the pollen seasons of the early flowering trees Alnus spp. and Corylus spp. in Worcester, United Kingdom, 1996-2005. International Journal of Biometeorology, 51, 181-191. https://doi.org/10.1007/s00484-0060059-2.

Feher, Z. and M. Jaria- Komlodi (1996). Relationship between airborne ragweed pollen and the macrosynoptic weather types in Budapest, Hungary. Ann. Agric. Environ. Med., 3: $121-126$.

Filbrandt-Czaja, A., and E. Adamska (2018). The analysis of the Corylus, Alnus and Betula pollen seasons in Torun 'in 2014 and 2016. Ecological Questions, 29(2), 51-60. https://doi. org/10.12775/EQ.2018.018.

Frei, T. (1998). The effects of climate change in Switzerland 1969-1996 on airborne pollen quantities from hazel, birch and grass. Grana. 37 (3): 172-179.

Frenguelli G, E. Bricchi, B. Romano, G. Mincigrucci, F.T.M. Spieksma (1989). A predictive study on the beginning of the pollen season for Gramineae and Olea europaea L. Aerobiologia., 5 (1): 64-70.

Gala'n, C., J. Emberlin, E. Domı'nguez, D. Bryant and F. Villamandos. (1995). A comparative analysis of daily variations in the Gramineae pollen counts at Co'rdoba, Spain and London, UK. Grana., 34:189-198.

Garcı 'a-Mozo, H., J. A. Oteros and C. Galan (2016). Impact of land cover changes and climate on the main airborne pollen types in Southern Spain. Sci. Total. Environ. 548-549: 221-228. https://doi.org/10.1016/j. scitotenv.2016.06.153 PMID: 27371770. 
Kim, S. H., H. S. Park and J. Y. Jang (2011). Impact of meteorological variation on hospital visits of patients with tree pollen allergy. BMC Public Health, 11, 890. https://doi. org/10.1186/1471-2458-11-890.

Kubik-Komar, A., K. Piotrowska-Weryszko, E. Weryszko-Chmielewska and B. M. Kaszewski (2018). Analysis of Fraxinus pollen seasons and forecast models based on meteorological factors. Annals of Agricultural and Environmental Medicine, 25(2), 285291. https://doi.org/10. 26444/aaem/80909.

Linkosalo, T., H. Ranta, A. Oksanen, P. Siljamo, A. Luomajoki (2010). A double-threshold temperature sum model for predicting the flowering duration and relative intensity of Betula pendula and B. pubescens. Agric. Meteor., 150(12): 1579-1584.

Mohammed E. S., Elfadil, A. G. and A. M. Musa (2020). Aeropalynological Survey of Pollen Grains in Khartoum City During 2018. $11^{\text {th }}$ Post-Graduate College Conference; Al Neelain University; Khartoum, Sudan, in press.

Muhammad, A. H. and R. Ghulam (2008). Effect of meteorological parameters on pollen concentration in the atmosphere of Islamabad. Pakistan Journal of Meteorology Vol. 4 Issue 8: January 2008.

Peel, M. C., B. L. Finlayson, T. A. McMahon (2007). "Updated world map of the KöppenGeiger climate classification" (PDF). Hydrology and Earth System Sciences. 11: 16331644.

Piotrowska-Weryszko, K. (2013). The effect of the meteorological factors on the Alnus pollen season in Lublin (Poland). Grana, 52(3), 221-228. https://doi.org/10.1080/ 00173134.2013.772653.

Puc, M. (2003). Characterization of pollen allergens. Ann. Agric. Environ.Med.,10: 143149.

Puc, M. and M. I. Puc (2004). Allergenic airborne grass pollen in Szczecin, Poland. Ann Agric Environ Med 2004, 11, 237-244.

Puc, M. (2004) Ragweed pollen in the air of Szczecin. Ann. Agric. Environ. Med., 11: 5357. PMID: 15236498.

Puc, M. and T. Wolski (2002). Betula and Populus pollen counts and metrological conditions in Szczecin, Poland. Ann. Agric. Environ. Med., 9:65-69. 
Recio M, A. Picornell, M. M. Trigo, D. Gharbi, J. Garc1 'a-Sa 'nchez (2018). Intensity and temporality of airborne Quercus pollen in the southwest Mediterranean area: correlation with meteorological and phenoclimatic variables, trends and possible adaptation to climate change. Agric. Meteor., 250-251: 308-318.

Rodr1 'guez-Rajo, F. J., A. Dopazo and V. Jato (2004). Environmental factors affecting the start of pollen season and concentrations of airborne Alnus pollen in two localities of Galicia (NW Spain). Annals of Agricultural and Environmental Medicine, 11, 35-44.

Scheifinger, H., J. Belmonte, S. Celenk, A. Damialis, C. Dechamp (2013). Monitoring, modelling and forecasting of the pollen season In: Sofiev M, Bergman C-K (Eds), Allergenic Pollen: a Review of the Production, Release, Distribution and Health Impacts. Springer Verlag.: 71-126.

Vega-Maray, A. M., R. Valencia-Barrera, D. Fernandez- Conzalez and R. Frail (2003). Urticaceae pollen concentration in the atmosphere of North Western Spain. Ann. Agric. Environ. Med., 10:249-255.Site Wikipedia.Org.com.2018 